enuresis from other causes of intermittent incontinence, such as retention with overflow or continuous urinary loss. An initial assessment would commonly have been made during childhood, when urinary tract infection would have been excluded. At some stage excretion urography should be arranged for the young patient with either unrelenting diurnal and nocturnal symptoms or atypical symptoms or signs, but it is usually best avoided until after puberty. Enuresis may be such an emotive problem that the radiological demonstration of a normal urinary tract may give considerable reassurance to the patient and relatives. Apart from providing a record of the bladder capacity under general anaesthesia, endoscopy rarely gives any useful clinical information, but it should be performed if the urine is infected or the urographic findings are abnormal. Trabeculation of the bladder and a prominent bladder neck may be evident, but these appearances should not be taken as evidence of outflow tract obstruction. ${ }^{7}$ The pathophysiology of enuresis seems to be related to the neurological control of bladder and sphincteric function. As many as $70 \%$ of adult patients have abnormal findings on cystometry, and the common finding is that of an unstable bladder showing detrusor contractions during filling or on provocation. ${ }^{4} 8$ The cause of this bladder instability is not known, but it is associated with trabeculation and the loss of the normal inhibitory influence of the nervous system on bladder contractility. This type of bladder instability is especially common in patients with diurnal/nocturnal enuresis. ${ }^{6}$ Hypertrophy of the sphincter, ${ }^{8}$ or its inappropriate relaxation on filling of the bladder, ${ }^{9}$ and incoordination of detrusor and sphincter activity ${ }^{10}$ have also been noted. Another factor is a pattern of unusually deep sleep, and electroencephalographic recordings have shown that most of those studied were deeply asleep at the moment of enuresis. ${ }^{11}$

The management of adult enuresis is essentially conservative and is based on improving bladder control. Adults who want to be cured may be taught the principles of bladder training. These patients usually have a small functional bladder capacity, ${ }^{12}$ and by maintaining a chart of their own frequency and voided volumes they learn to appreciate and to correct this. They are encouraged to hold increasing volumes of urine, up to $400 \mathrm{ml}$ or more, so that they will not need to empty the bladder during sleep. Bladder training can be reinforced with drugs such as emepronium bromide or propantheline; the combination has given good results when applied to the problem of urge incontinence associated with bladder instability in women. ${ }^{13}$ In some cases admission to hospital for up to 10 days may help in breaking the pattern of enuresis. Preliminary results on the use of DDAVP, a vasopressin analogue, have been encouraging, ${ }^{14}$ but a longer-term assessment is needed.

Surgery has a limited place in the treatment of adult enuresis. Attempts to modify the neurological control of the bladder by division of the sacral nerves ${ }^{15}$ or the detrusor ${ }^{16} 17$ have proved disappointing. Transection of the bladder may not alter the urodynamic state, and this operation should be strictly reserved as a last hope for patients with intractable enuresis. ${ }^{18}$

${ }^{1}$ Miller A. Adult enuresis. BrF Urol 1966;38:697-9.

${ }^{2}$ Miller FJW. Children who wet the bed. In: Kolvin I, MacKeith RC, Meadow SR, eds. Bladder control and enuresis. London: Heinemann, 1973:47-52. (Clinics in Developmental Medicine Nos 48/49.)

${ }^{3}$ Hindmarsh JR, Byrne PO. Adult enuresis-a symptomatic and urodynamic assessment. Brf Urol 1980;52:88-91.

4 MacKeith RC. Is maturation delay a frequent factor in the origins of primary nocturnal enuresis? Dev Med Child Neurol 1972;14:217-23.

5 Yeates WK. Bladder function: increased frequency and nocturnal incontinence. In: Kolvin I, MacKeith RC, Meadow SR, eds. Bladder control and enuresis. London: Heinemann, 1973:151-5. (Clinics in Developmental Medicine Nos 48/49.)

${ }^{6}$ Whiteside CG, Arnold EP. Persistent primary enuresis: a urodynamic assessment. Br Med f 1975 ; : 364-7.

7 Johnston JH, Koff SA, Glassberg KI. The pseudo-obstructed bladder in enuretic children. BrF Urol 1978;50:505-10.

8 Torrens MJ, Collins CD. The urodynamic assessment of adult enuresis. Brf Urol 1975;47:433-40.

${ }^{9}$ Franksson C, Petersen I. Electromyographic investigation of disturbances in the striated muscle of the urethral sphincter. Br $\mathcal{F}$ Urol 1955;27: 154-61.

10 Schafer W, Abrams PH. Voiding patterns of adult enuretics. In : Proceedings of the IX ICS Meeting, Rome 1979.

${ }^{11}$ Pierce CM. Dream studies in enuresis research. Can Psychiatr Assoc $\mathcal{F}$ $1963 ; 8: 415-9$.

12 Hallman N. On the ability of enuretic children to hold urine. Acta Paediatrica $1950 ; 39$ :87-93.

${ }^{13}$ Frewen W. Role of bladder training in the treatment of the unstable bladder in the female. Urol Clin North Am 1979;6:273-7.

${ }^{14}$ Ramsden PD, Hindmarsh JR, Bowditch JDP, Price DA, Yeates WK. DDAVP for adult enuresis-a preliminary report. In: Proceedings of the IX ICS Meeting, Rome 1979.

15 Torrens M, Hald T. Bladder denervation procedures. Urol Clin North Am $1979 ; 6: 283-93$.

16 Warwick RTT, Ashken MH. The functional results of partial, subtotal and total cystoplasty with special reference to ureterocaecocystoplasty, selective sphincterotomy and cystocystoplasty. Br f Urol 1967;39: 3-12.

17 Essenhigh DM, Yeates WK. Transection of the bladder with particular reference to enuresis. Br f Urol 1973;45:299-305.

18 Janknegt RA, Moonen WA, Schrienemachers LMH. Transection of the bladder as a method of treatment in adult enuresis nocturna. $\mathrm{Br} \mathcal{F} \mathrm{Urol}$ $1979 ; 51: 275-7$.

\section{Pneumonia during the treatment of acute leukaemia}

Over the past 10 years infection has remained the main cause of illness and mortality among patients with acute leukaemia being treated with chemotherapy. The lungs are the single most common site of infection during both the induction of remission and maintenance treatment. ${ }^{1-6}$

Pneumonia occurs in about one-third of all adults during treatment, but until recently the rate in children was only $5 \% \cdot{ }^{127} \mathrm{~A}$ report this year on a group of children with acute lymphoblastic leukaemia has suggested that with the addition of methotrexate and the intensification of treatment regimens the rate is now higher: $28 \%$ of children were affected. ${ }^{8}$ Nevertheless, a causative organism was isolated in only $20 \%$ of these cases; this difficulty in diagnosis, together with the inclusion of a large number of cases of pneumocystis pneumonia occurring in the second month of treatment, make the increase difficult to interpret.

In adults the incidence of infection increases with the degree of neutropenia, which is itself principally related to the intensity of the chemotherapy. ${ }^{1-5}$ In patients with severe neutropenia the usual clinical presentation-the production of sputum and radiological signs of pneumonia-may be completely abolished, though these signs may return as the circulating neutrophil count recovers. ${ }^{4910}$ This impairment of the normal response of the lungs to infection makes interpretation of diffuse lung shadows in a chest radiograph of a feverish patient with neutropenia a common diagnostic problem.

Even with repeated culturing of samples of blood and sputum and serological testing an organism will be identified in less than a third of all cases. ${ }^{10}$ Direct sampling from the 
lower respiratory tract can increase the diagnostic rate, and transtracheal aspiration provides a useful method for the rapid collection of uncontaminated specimens on the ward. ${ }^{1012}$ A reliable bacteriological diagnosis substantially improves the chances of survival; but such a diagnosis can be made in only $60 \%$ of cases, even with open-lung biopsy. ${ }^{51013}$

Gram-negative bacteria are the principal pathogens, predominantly Escherichia coli and Klebsiella pneumoniae; isolations of Pseudomonas aeruginosa have declined in frequency over recent years. ${ }^{1-5}$ Treatment needs to be started quickly with broad-spectrum antibiotics if the high mortality associated with Gram-negative endotoxaemia is to be avoided. ${ }^{114} 15$ The combination of tobramycin and a cephalosporin is the most effective currently available, though it may be toxic for patients with impaired renal function. 41617

Treatment with antibiotics may need to be continued for as long as the patient remains neutropenic ${ }^{117}$; however, survival is most strongly associated with the recovery of an adequate number of circulating neutrophils. Granulocyte transfusions given during recovery improve the chances of survival of those patients with a proved bacterial infection. ${ }^{14} 18$ Failure to respond is a clear indication for a further search for resistant organisms or other pathogens, especially pneumocystis, fungi, and tuberculosis; if necessary all antibiotics may need to be withdrawn before the cultures are repeated. ${ }^{1-5}$

Pneumocystis carinii pneumonia is three times more common in children than in adults. It occurs mainly during maintenance chemotherapy. 51920 The risk has recently been shown to correlate with the degree of cellular immunosuppression, and this is greater with continuous than with intermittent administration of drugs. ${ }^{21}$ Usually diagnosis is extremely difficult unless open-lung biopsy is performed, ${ }^{20} 22$ and a trial of treatment may be more acceptable. High-dose co-trimoxazole is as effective as pentamidine isethionate and less toxic, but whatever drugs are given the mortality from pneumocystis infection remains high. ${ }^{142022} 23$

Candida and Aspergillus species are the major fungal pathogens and account for $5-10 \%$ of the pneumonias. ${ }^{1-5}$ Cultures or serological tests are diagnostic in only a quarter of cases, ${ }^{210}$ and even open-biopsy specimens may be sterile. The only proved treatment is by rapid progression to full therapeutic doses of amphotericin B. ${ }^{14}$ How useful the more recent imidazole compounds will be in these patients is not known. ${ }^{24}$

Serological tests and biopsy are even less helpful in the diagnosis of viral pneumonias-but these are not a big cause of mortality, with three exceptions: cytomegalovirus after bone marrow transplantation, measles virus in immunosuppressed children, and disseminated herpes zoster in patients with Hodgkin's disease..$^{5} 610$ 25-27

Much attention has also been given to the prevention of infection. Prophylaxis against tuberculosis is necessary for all patients who have had earlier infections. Bacterial decontamination of the bowel with non-absorbable antibiotics lowers the incidence of infection. The addition of a protected environment is of less certain benefit, but recent reports suggest a further reduction in the incidence of some infections and a consequent improvement in the remission rate and median survival. ${ }^{28-30}$ This experience is, however, by no means uniform. Long term, a more effective antibacterial regimen is required.

1 Bodey GP, Rodriguez V, Chang H-Y, Narboni G. Fever and infection in leukemic patients. A study of 494 consecutive patients. Cancer 1978;41: 1610-22.

${ }^{2}$ Chang H-Y, Rodriguez V, Narboni G, Bodey GP, Luna MA, Freireich EJ. Causes of death in adults with acute leukemia. Medicine (Baltimore) $1976 ; 55: 259-68$.

4 Valdivieso M, Gil-Extremera B, Zornoza J, Rodriguez V, Bodey GP. Gram-negative bacillary pneumonia in the compromised host. Medicine (Baltimore) 1977;56:241-54.

5 Winston DJ, Gale RP, Meyer DV, Young LS. Infectious complications of human bone marrow transplantation. Medicine (Baltimore) 1979;58:1-31.

${ }^{6}$ Atkinson K, Storb R, Prentice RL, et al. Analysis of late infections in 18 long-term survivors of bone marrow transplantation. Blood 1979:53: 720-31.

7 Chessells JM, Leiper AD. Infection during remission induction in childhood leukaemia. Arch Dis Child 1980;55:118-23.

${ }^{8}$ Siegel SE, Nesbit ME, Baehner R, Sather H, Hammond D. Pneumonia during therapy for childhood acute lymphoblastic leukemia. Am $\mathcal{f} D i s$ Child 1980;134:28-34

- Sickles EA, Young VM, Greene WH, Wiernik PH. Pneumonia in acute leukemia. Ann Intern Med 1973;79:528-34.

10 Singer C, Armstrong D, Rosen PP, Walzer PD, Yu B. Diffuse pulmonary infiltrates in immunosuppressed patients. Prospective study of 80 cases. Am f Med 1979;66:110-20.

12 Kalinske RW, Parker RH, Brandt D; Hoeprich PD. Diagnostic usefulness and safety of transtracheal aspiration. N Engl f Med 1967;276:604-8.

13 Greenman RL, Goodall PT, King D. Lung biopsy in immunocompromised hosts. Am $\mathcal{F}$ Med 1975;59:488-96.

14 Ketchel SJ, Rodriguez V. Acute infections in cancer patients. Semin Oncol $1978 ; 5: 167-79$

15 Whitecar JJP, Luna M, Bodey GP. Pseudomonas bacteremia in patients with malignant diseases. Am $\mathcal{F}$ Med Sci 1970;260:216-23.

${ }_{16}$ The EORTC International Antimicrobial Therapy Project Group. Three antibiotic regimens in the treatment of infection in febrile granulocytopenic patients with cancer. $\mathcal{F}$ Infect Dis 1978;137:14-29.

17 Pizzo PA, Robichaud KJ, Gill FA, et al. Duration of empiric antibiotic therapy in granulocytopenic patients with cancer. Am f Med 1979;67: 194-200.

18 Alavi JB, Root RK, Djerassi I, et al. A randomized clinical trial of granulocyte transfusions for infection in acute leukemia. N Engl f Med 1977; 296 ; $706-11$.

${ }^{19}$ Hughes WT, Smith DR. Infection during induction of remission in acute lymphocytic leukemia. Cancer $1972 ; 31: 1008-14$.

20 Wolff LF, Bartlett MS, Baehner RL, Grosfeld JL, Smith JW. The causes of interstitial pneumonitis in immunocompromised children: an aggressive systemic approach to diagnosis. Pediatrics 1977;60:41-5.

${ }^{21}$ Rapson NT, Cornbleet MA, Chessels JM, Bennett AJ, Hardisty RM. Immunosuppression and serious infections in children with acute lymphoblastic leukaemia: a comparison of three chemotherapy regimes. Br f Haematol 1980;45:41-52.

22 Rosen PP, Martini N, Armstrong D. Pneumocystis carinii pneumonia. Diagnosis by lung biopsy. Am $\mathcal{F}$ Med 1975;58:794-802.

${ }^{23}$ Hughes WT. Protozoa infections in haematological diseases. Clin Haematol $1976 ; 5: 329-46$.

24 Codish SD, Tobias JS, Hannigan M. Combined amphotericin Bflucytosine therapy in aspergillus pneumonia. $\mathcal{F} A M A$ 1979;241:2418-9.

${ }^{25}$ Feld R, Bodey GP. Infections in patients with malignant lymphoma treated with combination chemotherapy. Cancer 1977;39:1018-25.

${ }^{26}$ Neiman PE, Thomas ED, Reeves WC, et al. Opportunistic infection and interstitial pneumonia following marrow transplantation for aplastic anemia and hematologic malignancy. Transplant Proc 1976;8:663-7.

27 Craft AW, Reid MM, Gardener PS, et al. Virus infections in children with acute lymphoblastic leukaemia. Arch Dis Child 1979;54:755-9.

28 Schimpff SC, Greene WH, Young VM, et al. Infection prevention in acute nonlymphocytic leukemia. Laminar air flow room reverse isolation with oral, nonabsorbable antibiotic prophylaxis. Ann Intern Med 1975;82: 351-8.

${ }^{29}$ Rodriguez V, Bodey GP, Freireich EJ, et al. Randomized trial of protected environment-prophylactic antibiotics in 145 adults with acute leukemia. Medicine (Baltimore) 1978;57:253-66.

${ }^{30}$ Lohner D, Debusscher L, Prevost JM, Klastersky J. Comparative randomized study of protected environment plus oral antibiotics versus oral antibiotics alone in neutropenic patients. Cancer Treat Rep 1979;63: 363-8. 